with two turns of fine thread. The plane of vibration can then be easily adjusted to suit the spectators by sluing the wire in its lashing.

Note.-The triangular thread $d$ A $e$ should be of the same quality as the vibrating length. If it is much heavier length for length the arms of the triangle may become half wave-lengths of the vibration for the tension employed, and then they lose their control over the plane of vibration.

The arrangement has its own worth, independently of the aid it lends to visible effect, as an illustration of the suppression of all half wave-lengths which are not true sub-multiples of the vibrating length of the cord. When the fork is moved from its position in the figure to bring up the line de to the position of A, the vertical vibrations are suppressed, and only the horizontal vibrations are possible.

W. Sidgreaves.

\section{EIGHTH CONGRESS OF RUSSIAN NATURALISTS.}

THE eighth Congress of Russian Naturalists and Physicians was opened on January 9 at St. Petersburg, and was a great success. It was attended by no fewer than 2000 members, half of whom came from the provinces, and at the three general public sittings (corresponding to the sittings of the British Association devoted to the delivery of the Presidential addresses), as well as the meetings of the Sections, the public were well reprejented. At the first general sitting, Prof. Mendeleeff delivered a most interesting address on the methods of natural science as applied to the study of prices. His parallels between the prices of goods and the specific weights and specific volumes of chemical bodies were very suggestive. The next address, by Prof. Sklifasovsky, was on the wants of Russian medical education. At the second general sitting, Prof. Stoletoff spoke of ether and electricity. Prof. Famintzyn's address on the psychical life of the simplest representatives of living beings, partly based upon his own recent researches into the intelligence of Infusoria, was full of facts as to the means used by various micro-organisms in attack and defence. Prof. Wagner dealt with the physiological and psychological views upon hypnotism, and Prof. Gustavson spoke of the micro-biological bases of agronomy.

The work of the Sections was very varied, and will be fully rep rted in the Diary of the Congress, the publication of which began during the sitting of the Congress, and will be continued till a full account has been produced.

The Sections of Geography and Anthropology, Hygiene, and partly of Agronomy, were most largely attended, and many interesting communications were made in them. At the combined sittings several important questions were raised as to the geography of Russia, its meteorology, and the bearings of a scientific study of climate and soil upon agriculture.

The following communications relative to gengraphy and anthropol igy were especially worthy of note. Captain Makaroff reported the results of his careful measurements as to the differences of level of various seas of Europe. Taking the average level of the Atlantic Ocean opposite Lisbon for zero, he found that the level of the western parts of the Mediterranean is 434 millimetres below zero, its eastern part, - 507 millimetres; the Egean Sea, - 563 millimetres ; the Marmora Sea, from - 360 to -291 millimetres; while the Black Sea is +246 millimetres -that is, higher than the Lisbon zero; the western part of the Baltic, +259 millimetres ; its eastern part, +254 millimetres; and the Gulf of Finland, +415 millimetres. Dr. Blum's anthropolngical measurements amidst twelve different tribes of the Caucasus show that there are no pure race; in Caucasia, all of them being mixtures between Semitic and Indo-European races. Like conclusions were arrived at by $M$. Kharuzin as regards the Bashkires, who proved to be a mixed race, presenting features both of the Mongolian and the Caucasian races.

Prof. Klossovsky's researches into the variations of level and cemperature in the coast region of the Black Sea are most valuable, as they are based on accurate measurements made since I 879 at I 6 different places. They fully disclose the importance of atmospheric pressure upon the level of the Black Sea, and it is wiorthy of note that the passage of a cyclone over Odessa resulted in a rise of the level of the sea by fully 5 feet over the average, followed by a sinking of the level by fully 7 feet, in accordance with the variations of atm ospheric pressure.

Dr. Orzanski's extensive anthropological researches amidst the population of Russian prisons, and his numerous measurements, show no difference between the supposed "criminal's skull" and the average Russian skull. Numerous photographs were exhibited to illustrate this conclusion, so different from those arrived at by Dr. Lombroso.

Two new periodicals- - one of them devoted to Russian natural science, and the other to meteorology-were founded while the Congress was at work. The meeting came to an end on January 20

The Congress hoped to obtain from the Government permission to appoint a permanent Board, and thus to lay the foundation of a Russian Association for the Advancement of Science.

\section{TECHNICAL EDUCATION IN ELEMENTARY SCHOOLS.}

THE Committee of the National Association for the Promotion of Technical and Secondary Education have submitted to the Education Department the following suggestions for the modification of the Code as regards elementary technical education :-

\section{A.-Drazuing.}

(I) Drawing to be introduced in infant schools, at least for boys.

(2) Drawing to be made compulsory in boys' schools.

(3) The Minute requiring cookery to be taught in girls' schools as a condition of receiving grant for drawing, to be repealed!

\section{B. - Object Lessons.}

(4) No school to be recognized as efficient which does not provide in the three lower standards a graduated scheme of object lessons in continuation of Kindergarten instruction in the infant school.

$$
\text { C.--Science. }
$$

(5) In order to encourage science as a class subject, the clause requiring English as one of the class subjects to be cancelled, and the teaching of science as a class subject to be further encouraged in the upper standards by an additional grant.

(6) Scholars of any public elementary school to be allowed to attend science classes held at any place approved by the inspector, and such attendance to count as school attendance.

(7) Examinations in science to be conducted orally, and not on paper, especially in the first five standards. If the inspection is satisfactory, an attendance grant of $4^{s}$. to be made for scientific specific subjects.

(8) Managers to be encouraged to submit alternative course of instruction in specific subjects under Art. I6 (Code I888). Such subjects to receive a grant on the same principle as the subjects enumerated in Art. I5.

[Art. r6. "Any other subject other than those mentioned in Art. I 5, may, if sanctioned by the Department, be taken as a specific subject, provided that a graduated scheme of teaching it be submitted to and approved by the inspector."

But Art. IO9 $(g)$ which lays down the condition for grants, says, "The specific subjects which may be taken are those enumerated in Art. 15."]

(9) Grants to be made towards apparatus for science teaching and school museums.

\section{D.-Manual Instruction.}

(I0) Manual instruction to be introduced in boys' schools, corresponding to needlework for girls.

(II) Instruction in the use of simple tools to be introduced in the higher standards as a specific subject, and grants to be paid thereon.

(12) Provision to be made for the introduction of elementary modelling in connection with the teaching of drawing, and a grant to be made in connection therewith.

(13) Instruction in laundry work to be encouraged in girls schools, so far as practicable, as a part of domestic economy.

$$
\text { E.-Evening Schools. }
$$

(I4) The clause providing that "No scholar may be presented for examination in the additional subjects alone" to be cancelled, to enable scholars to earn grants though not receiving instruction in the standard subjects. 